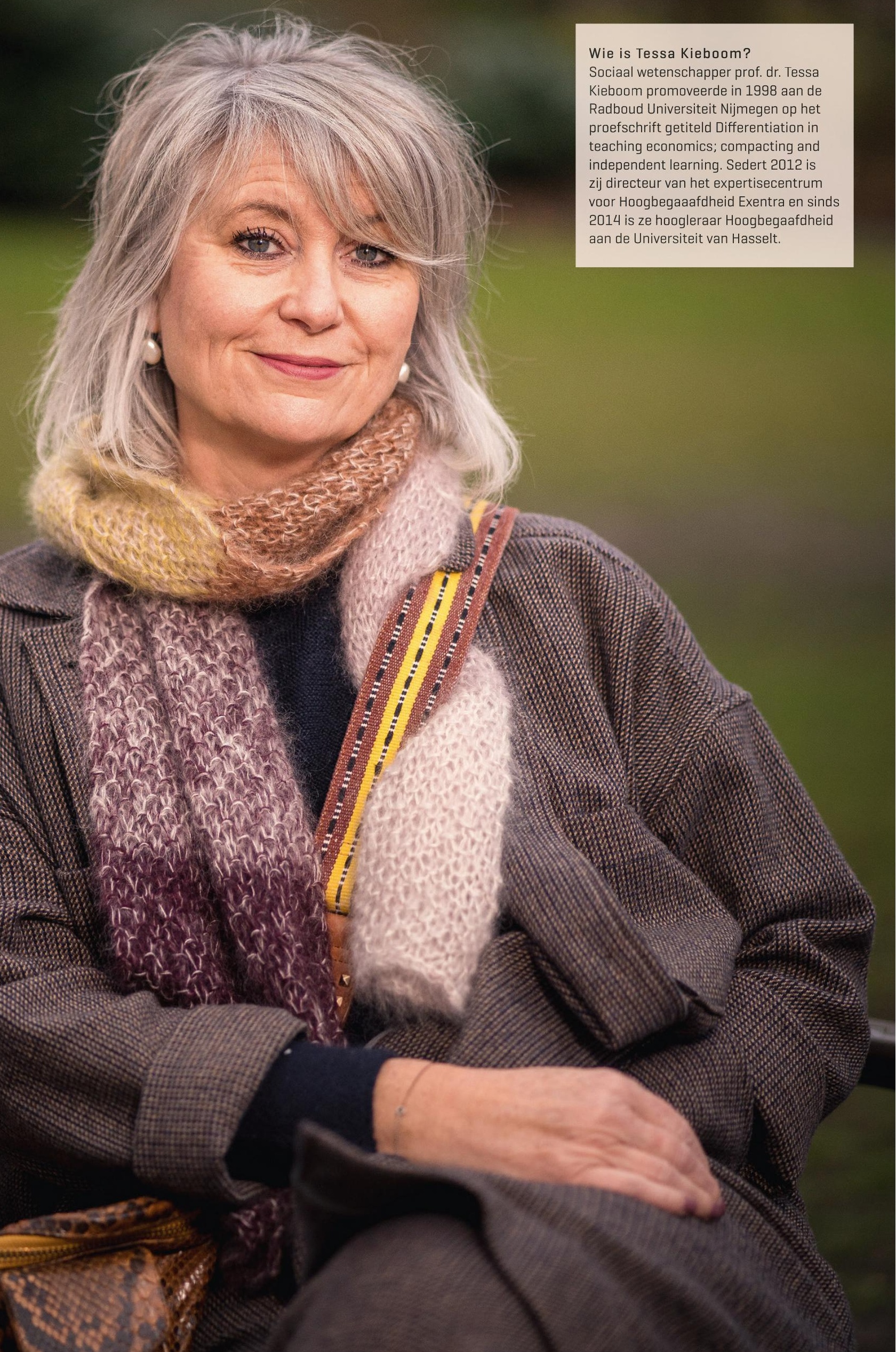




\section{Koester hoogbegaafden door ze op tijd te ontdekken}

Patrick Marx, Mascha Witteman-de Kok

Hoogbegaafdheid is geen ziekte. Er bestaat geen ICPC-code voor noch zijn er specifieke richtlijnen voor de diagnostiek en behandeling. Ook is er weinig literatuur over. Huisartsen zullen dan ook niet vaak hieraan denken als oorzaak van klachten. Toch kunnen kinderen van hun hoogbegaafdheid ziek worden, vooral als deze eigenschap maar lang genoeg onopgemerkt blijft. Een onbegrepen en ongelukkige jeugd ligt dan op de loer en als volwassenen komen ze niet tot hun recht. Het zou fijn zijn als huisartsen vaker de diagnose 'hoogbegaafdheid' overwegen en daarmee kinderen de erkenning geven die ze vaak ontberen.

Op je spreekuur zie je de 9-jarige Sjoerd met zijn moeder, die zich zorgen om hem maakt; op school is hij lastig en hij voert niets uit, terwijl zijn ouders altijd het idee hebben gehad dat het een pientere jongen is. Thuis besteedt hij de laatste maanden uren per dag aan het natekenen van stripfiguren uit de Donald Duck, soms tot ergernis van de ouders.

Sjoerd zou een voorbeeld kunnen zijn uit de kersverse negentiende druk van Hoogbegaafd. Als je kind ( $g$ )een Einstein is. De jongen geeft er geen blijk van hoogbegaafd te zijn, hij is het echter wel. Zijn houding op school is daar het gevolg van. Hij krijgt niet de erkenning als hoogbegaafde, hij verveelt zich altijd op school en hij speelt nooit met gelijkgestemden. Hij voelt zich misplaatst, een gevoel dat hem zijn hele leven kan blijven achtervolgen. 'Zodra hoogbegaafde mensen die de erkenning van hun gave missen 50-60 jaar zijn, kunnen ze hun leven als mislukt beschouwen', zegt auteur Tessa Kieboom. Ze is hoogleraar hoogbegaafdheid aan de Universiteit van Hasselt en directeur van Exentra, het expertisecentrum rond hoogbegaafdheid in Antwerpen.

\section{Brein en zijn}

Het tijdig opsporen van de ongeveer 2,5\% hoogbegaafde ( $\geq$ IQ 130) Nederlandse kinderen is dus belangrijk om psychosociale problemen bij sommige van hen te voorkomen. De 2,5\% is een veelgebruikte schatting op basis van een normaalverdeling, waarbij een IQ van 100 gemiddeld is en een IQ $\geq 1302$ standaarddeviaties afwijkt van het gemiddelde. Kieboom legt uit wat ze onder hoogbegaafdheid verstaat: 'Hoogbegaafdheid kenmerkt zich in het brein en het zijn. Iedereen denkt bij hoogbegaafdheid aan kinderen met een IQ $\geq 130$. Het zijn kinderen met een sterke intelligentie die doorgaans creatief, out-of-the-box denken. Ze leggen snel verbanden en vinden snel oplossingen. Denk aan een 4 -jarige die weet hoe de dinosauriërs uitstierven en vervolgens vraagt wanneer de mens uitsterft.'

Het intelligente brein heeft op 4 vlakken zijn weerslag op het zijn van de kinderen. Kieboom: 'Ten eerste hebben ze een uitgesproken rechtvaardigheidsgevoel. Ten tweede zijn ze gevoeliger omdat ze sneller dan leeftijdgenoten de impact van zaken, zoals COVID-19 of het klimaat, doorhebben. Dit leidt tot piekeren, slecht slapen of nachtmerries. Hierbij hoort ook het zoeken naar authenticiteit, naar mensen die eerlijk en oprecht vertellen wat ze menen. Een huisarts die uitstraalt dat er iets mis is, maar dat niet vertelt, zullen ze niet als authentiek beschouwen, om vervolgens een afwachtende houding aan te nemen. Ten derde hebben hoogbegaafde kinderen een kritische instelling tegenover mensen en zaken. Ze stellen kritische vragen en vragen door naar details.'

Volgens Kieboom is het vierde aspect automatisch gekoppeld aan hoogbegaafdheid. 'Hoogbegaafde mensen leggen onbewust de lat steeds hoger. Als de juffrouw op school de klas vraagt een appel te tekenen, dan is ze allang blij als iedereen een appel tekent en geen banaan. Een hoogbegaafd kind denkt dat het een perfecte appel moet tekenen, zoals op een foto. Als dit niet lukt, volgt frustratie. Het kind denkt negatief over zichzelf omdat het ervan uitgaat dat het geen perfecte appel kan tekenen of het kijkt naar tekeningen van klasgenoten en tekent ook zo'n appel.'

\section{Lichamelijke klachten}

De invloed van deze 4 vier aspecten van hoogbegaafdheid zorgt voor problemen, mits niet tijdig herkend. Kinderen vervelen zich op school, omdat ze de hele dag bezig zijn met dingen die ze al weten. Ze vinden moeilijk aansluiting bij andere kinderen. Ze passen zich aan het niveau van hun klasgenoten aan en gaan zo beneden hun kunnen 
presteren. Kieboom: 'We zien ook lichamelijke klachten zoals buikpijn of bedplassen waarmee ouders en kind de huisarts bezoeken. Als ze dat vaak genoeg doen, gebeurt het dat het kind medisch binnenstebuiten wordt gekeerd. Doorgaans wordt niets gevonden, maar de klachten houden aan.' Een andere reden waarmee ouders de huisarts bezoeken, zijn opvoedingsproblemen. 'Ouders klagen dat hun kind moeilijk opvoedbaar is, woede-uitbarstingen heeft en veel met hen in discussie gaat. Te snel denkt een arts dan aan een ontwikkelingsstoornis, terwijl de klachten een uiting zijn van frustratie na bijvoorbeeld weer een dag verveling op school.'

\section{Signalen}

'Het is goed als artsen meer vragen naar hoe het op school gaat', vervolgt Kieboom. 'Het antwoord op die vraag kan juist een aanwijzing voor hoogbegaafdheid zijn. Hoogbegaafde kinderen geven signalen af. Ze stellen vragen over bijvoorbeeld de stethoscoop en willen dan details weten over hoe deze werkt, ze spreken vlot voor hun leeftijd of zijn juist erg afwachtend omdat ze kijken of je wel authentiek handelt. Soms is de schreeuw om hulp zo groot dat 7-8 jarigen roepen dat ze dood willen, ze hebben er immers niet om gevraagd om geboren te worden. Kortom, doorvragen naar prestaties op school en de interesses van een kind kan een lichtje over hoogbegaafdheid doen branden.

Een gevalideerde vragenlijst voor het opsporen van hoogbegaafdheid bestaat niet. Een huisarts kan bij een vermoeden van hoogbegaafdheid wel verwijzen. In Nederland wordt veelal verwezen naar een orthopedagoog, soms naar een kinderpsycholoog. Verwijs altijd naar een zorgverlener die affiniteit heeft met hoogbegaafden. Een gewone psycholoog zal een IQ-test afnemen volgens de regeltjes. Iemand die affiniteit heeft met hoogbegaafdheid weet dat hoogbegaafden uit zichzelf de handdoek in de ring gooien als ze niet meer $100 \%$ zeker zijn van het goede antwoord. Deze zullen dus doorvragen, waardoor de uitslag op de test inderdaad omhooggaat. Kieboom: 'Nederland kent geen kwaliteitsregister voor deze zorgverleners. De huisarts zal op eigen (verwijs)ervaringen af moeten gaan bij het maken van een keuze.' Ervaringsdeskundigen pleiten voor verwijzing naar een orthopedagoog met als aandachtsgebied hoogbegaafdheid.

Een IQ-test kan zeker helpen bij het vaststellen van hoogbegaafdheid, maar is niet zaligmakend. 'Bij een score vanaf 130 is sprake van hoogbegaafdheid. Maar kinderen die moeite hebben om te presteren, zullen vaker te laag scoren.' Ook scholen kunnen, op basis van hun ervaring, overigens het vermoeden van hoogbegaafdheid benoemen, maar dat is sterk afhankelijk van de kennis over dit onderwerp bij de school, bijvoorbeeld bij een remedial teacher, die vaak 'opvallende kinderen' begeleidt. Op veel Nederlandse scholen ontbreekt het aan leerkrachten met goede kennis hierover. Het gevolg is dat veel ouders tegen een muur lopen. Vaak wordt het kind als 'lastig' bestempeld en wordt geadviseerd langs te gaan bij de huisarts. Als ouders het idee hebben dat ze op school tegen een muur aanlopen, is het advies om het verder te zoeken; vaak weet bijvoorbeeld het samenwerkingsverband van scholen wie er ingeschakeld kan worden om het kind extra te begeleiden.

\section{Mentale sterkte}

Zodra hoogbegaafdheid in beeld komt, is het zaak het kind goed te begeleiden. 'Differentiatie naar boven toe maar ook een "plusklas" helpen daarbij', zegt Kieboom. 'Maak het de kinderen moeilijk en kweek zo mentale sterkte aan. Het kind moet leren zijn potentieel te gebruiken. Op de basisschool is de lesstof vaak te makkelijk, te veel gaat daardoor vanzelf, ze maken weinig fouten en leren snel. Ze hoeven geen studiemethodieken te ontwikkelen en kweken daardoor geen mentale sterkte en doorzettingsvermogen.' Aanvullend: in Nederland bieden steeds meer scholen voltijds hoogbegaafdenonderwijs aan.

Het gebrek aan mentale sterkte kan zich wreken zodra het kind de puberleeftijd bereikt. 'Als gevolg van faalangst en de angst te laten zien wat ze kunnen, worden ze onzeker en krijgen ze een negatief zelfbeeld. Ze komen dan vaak in de geestelijke gezondheidszorg terecht. We moeten daarom stoppen om de ontwikkeling van mentale sterkte van hoogbegaafde kinderen aan het toeval over te laten. Hoe mentaal sterker het kind, hoe beter het zijn potentieel zal benutten en hoe gelukkiger het in zijn latere leven zal zijn.'

\section{Onderzoek en opleiding}

Kiebooms expertisecentrum in Antwerpen richt zich niet alleen op psychologisch onderzoek, maar ontwikkelt ook educatie voor ouders, leerkrachten en artsen over hoogbegaafdheid. 'Voor artsen hebben we enkele kortdurende nascholingen over het herkennen van hoogbegaafdheid', zegt de hoogleraar.

Was Einstein, uit de titel van Kiebooms boek, hoogbegaafd? Uit Frieda Wishinsky's biografie Albert Einstein blijkt dat hij zich als 5-jarige al afvroeg welke kracht een kompasnaald naar het noorden richt. Hij maakte geen vrienden op de basisschool en werd op het gymnasium uitgelachen vanwege zijn hoge rechtvaardigheidsgevoel. Zijn leraren vonden dat hij in niets uitblonk. Maar, eenmaal uitgedaagd, wist hij elk mathematisch probleem tot een goed einde te brengen. De signalen voor hoogbegaafdheid waren zeker aanwezig. Kieboom: 'Het is weinig hoogbegaafden gegeven om zonder hulp op latere leeftijd zo te excelleren en een maatschappelijk relevante bijdrage te leveren. We zouden hen daarom moeten koesteren om verlies van hun potentieel te voorkomen.'

\section{Voor $u$ als huisarts}

Zoals altijd: luister en kijk goed naar uw patiënt en diens familie. Bespreek de mate van het rechtvaardigheidsgevoel, hoe gevoelig de patiënt is voor bijvoorbeeld het nieuws en hoe hij probeert deze in een context te plaatsen. Bespreek een onderwerp dat hem interesseert en ga na hoe gedetailleerd zijn kennis op dat gebied is. Exploreer het zelfbeeld van de patiënt en vraag ten slotte naar lichamelijke klachten en opvoedingsproblemen. 